\title{
GEOCHEMISTRY OF THE AUPUK GAS SEEP ALONG THE COLVILLE RIVER-EVIDENCE FOR A THERMOGENIC ORIGIN
}

\author{
by
}

\author{
Paul L. Decker ${ }^{1}$ and Marwan A. Wartes ${ }^{2}$
}

\section{INTRODUCTION}

The Brooks Range Foothills of Alaska's North Slope are generally considered gas prone with mean estimates of undiscovered, technically recoverable natural gas reported in the tens of trillions of cubic feet (Houseknecht and Bird, 2006; Garrity and others, 2005; Bird and Houseknecht, 2002; Schuenemeyer, 1999). Despite the large size of this assessed resource, the province remains underexplored and more data are required to evaluate details of the gas component of the petroleum system (for example, Nelson and others, 2006; Burruss and others, 2003).

This report summarizes new data from the Aupuk gas seep along the Colville River (Ikpikpuk River Quadrangle; fig. 1). The gas seep was discovered by a U.S. Navy geological field party in 1945 near Kakvuiyat Bend upstream of the confluence of Aupuk Creek with the Colville River (figs. 1 and 2). The area was revisited in 1946, 1947, and 1950 by U.S. Geological Survey (USGS) field parties (Chapman and others, 1964). Compositional data from samples analyzed in 1946 were reported by Chapman and others (1964) and indicated the seep was dominated by methane, although available technology did not allow them to assess whether the gas was biogenic or thermogenic.

During recent stratigraphic investigations of the Albian-Cenomanian Nanushuk Formation (LePain and others, 2008, this volume), we were able relocate the still active seep and sample it for modern geochemical analyses. Three gas samples were collected from the seep during 2005 and 2006 and analyzed for both molecular composition and stable isotopic data.

\section{SEEP DESCRIPTION AND SAMPLE COLLECTION}

The seep is located in a small meander scar lake shown in figure 2. Rubbly exposures of Nanushuk Formation sandstone form the moderately steep slope immediately south of the seep. During the first visit in 2005, gas bubbles emanated from a single point in water less than $60 \mathrm{~cm}$ deep on the south side of the lake, approximately $12 \mathrm{~m}$ from

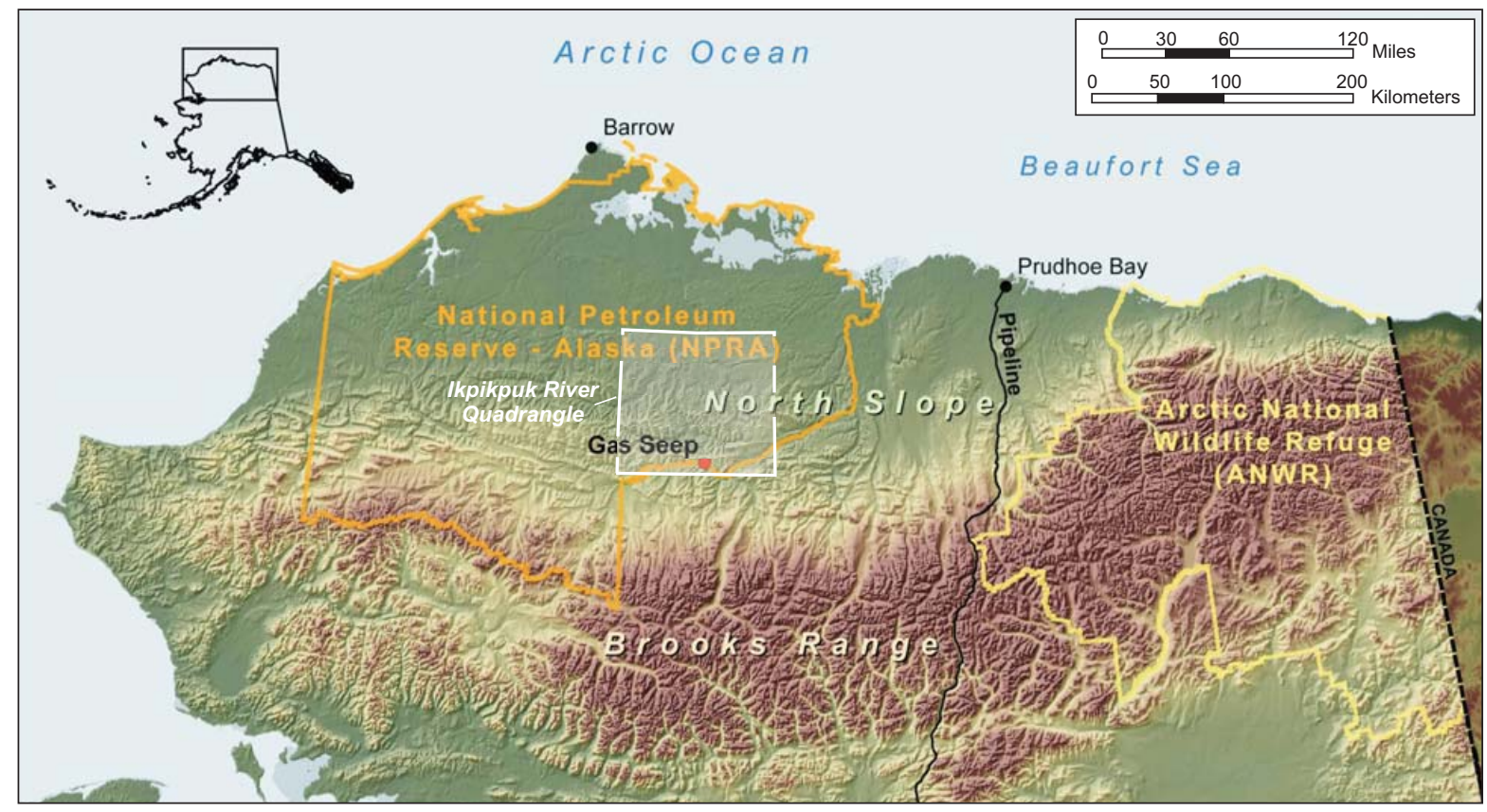

Figure 1. Regional map of northern Alaska showing location of the Aupuk gas seep. See figure 2 for more detailed map and coordinates.

${ }^{1}$ Alaska Division of Oil \& Gas, 550 W. 7th Ave., Suite 800, Anchorage, Alaska 99501-3560

Email for Paul L. Decker: paul.decker@alaska.gov

${ }^{2}$ Alaska Division of Geological \& Geophysical Surveys, 3354 College Rd., Fairbanks, Alaska 99709-3707 


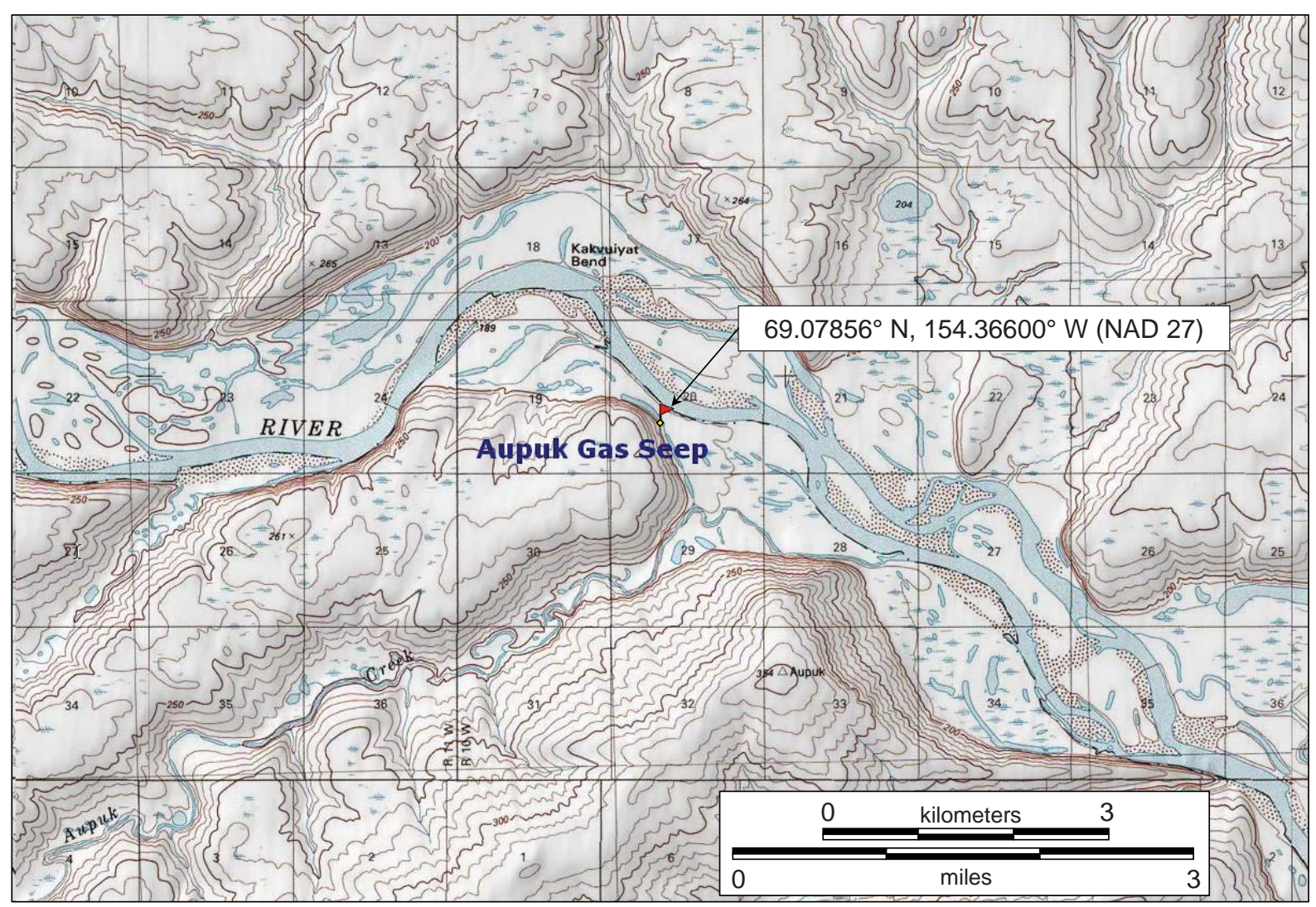

Figure 2. Location of the Aupuk gas seep sampled during the 2005 and 2006 field seasons, between Kakvuiyat Bend and the confluence of Aupuk Creek on the Colville River.

the southeast end (fig. 3). Bubbles rose from the lake bottom in continuous streams lasting 2-3 seconds with no more than 15 seconds between subsequent episodes ${ }^{3}$. In 2006, the seep was far more active, with approximately 20 bubble streams observed within a $\sim 15 \mathrm{~m}$ radius, a level of activity analogous to that observed in the early USGS investigations (Chapman and others, 1964). The 2006 samples were collected from what appeared to be the same vent as the 2005 sample. All samples were collected by allowing the bubbles to displace approximately $200 \mathrm{ml}$ of water from an inverted $250 \mathrm{ml}$ I-Chem amber glass sample bottle (fig. 3d).

The 2005 sample was analyzed for composition at CoreLab in Calgary, Alberta, then forwarded to the Department of Earth and Ocean Sciences at the University of Victoria in Victoria, British Columbia, for methane isotope analysis. Two additional gas samples were collected in 2006 and analyzed at Intertek Westport Technology Center, Houston, Texas.

\section{COMPOSITION AND METHANE ISOTOPIC ANALYSIS}

Table 1 presents results for all known analyses of the Aupuk gas seep, including data from 1946 reported in Chapman and others (1964). Because of known or suspected air leakage into their samples, Chapman and others (1964) reported the gas composition in two columns: column A gives the composition on a dry basis but including air, and column B gives results on a dry, air-free basis. No specific explanation is given for how the air-free results were derived, but the nitrogen, oxygen, and argon values in column B appear to have been recalculated by assuming all the oxygen in column $\mathrm{A}$ was due to air leakage, and adjusting the nitrogen and argon values in direct proportion to their ratios with oxygen in air. In any event, their compositions range from approximately 95 percent methane (including air, column A) to approximately 99 percent methane (on a dry, air-free basis, column B), with traces of nitrogen, carbon dioxide, argon, and heavier gas species.

\footnotetext{
${ }^{3}$ See 19-second QuickTime movie clip illustrating the nature and rate of gas seepage during the 2005 visit $<$ http://www.dggs.dnr.state.ak.us/pubs/pubs?reqtype=citation\&ID $=16084>$.
} 

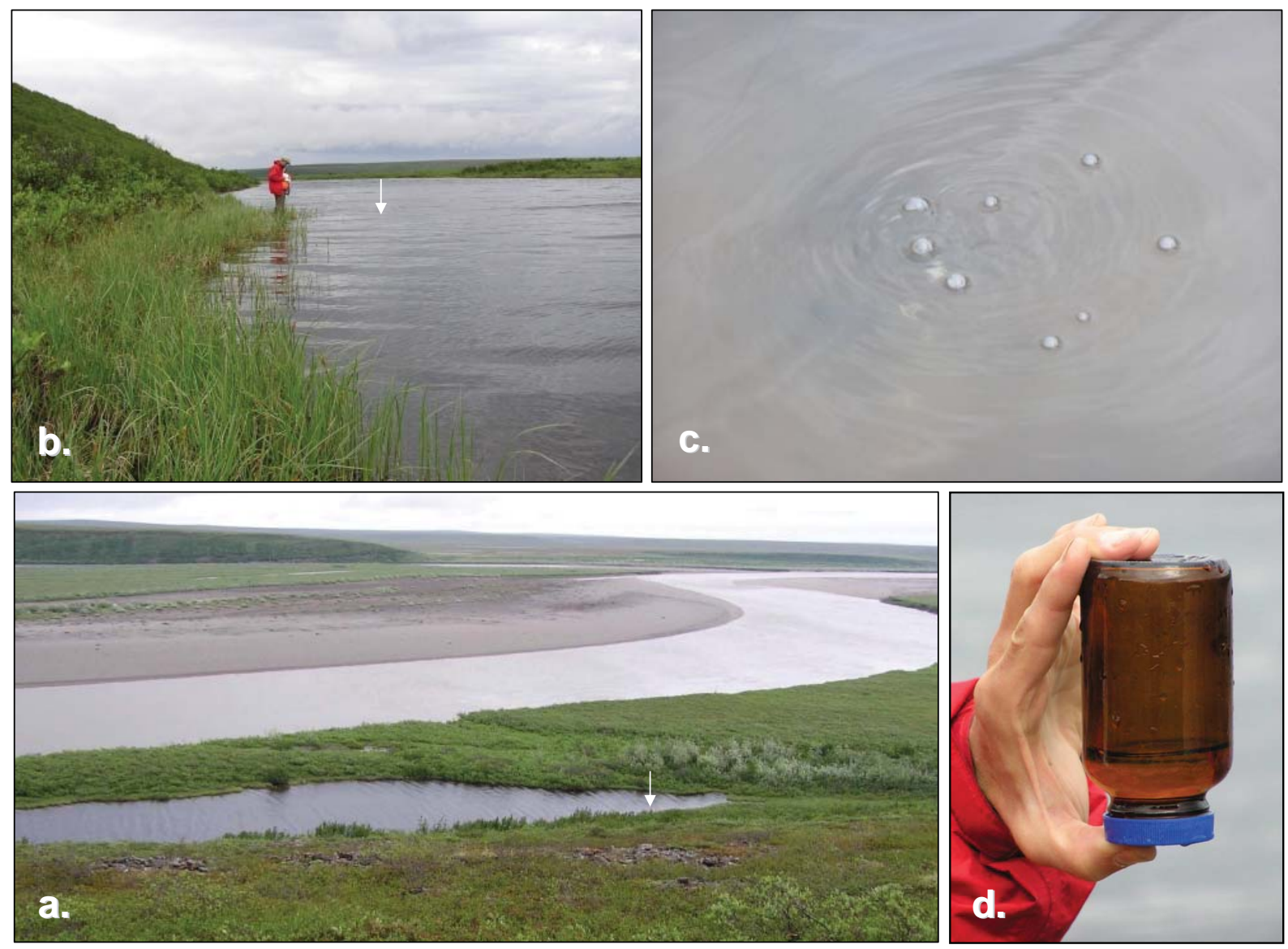

Figure 3. Field photos of the Aupuk gas seep near Kakvuiyat Bend on the Colville River. (a) View to northeast of small meander scar lake immediately south of Colville River. (b) View to northwest at sample location on south shore of lake. During the 2005 visit, the gas bubbles emanated from a single point in water less than $60 \mathrm{~cm}$ deep near the south side of the lake approximately $12 \mathrm{~m}$ from the southeast end [arrows in (a) and (b)]. In 2006, numerous bubble streams were active within a radius of approximately $15 \mathrm{~m}$ from sample location. Gas samples were collected by allowing bubble stream (c) to displace approximately $200 \mathrm{ml}$ of water from an inverted $250 \mathrm{ml}$ I-Chem amber glass sample bottle (d).

Similar to other analyses of gas in the Brooks Range Foothills (Burruss and others, 2003), data from the Aupuk seep indicate a very dry gas, containing mostly methane with negligible ethane and heavier hydrocarbons (table 1). However, all three of our recent samples yielded significantly higher nitrogen content than gas sampled from the same seep in 1946 (table 1). The reason for the high nitrogen content is not clear. Most natural gases from the North Slope contain less than 4 mole percent nitrogen (Burruss and others, 2003), and air contamination is blamed for higher nitrogen content in some cases. However, the ratio of nitrogen to oxygen in sample 05PD034 (235:1) is orders of magnitude higher than the ratio in air (3.25:1), so only a small fraction of the nitrogen can be readily explained by air leakage alone. Sample 06PD004a yielded a much lower methane and much higher nitrogen content than any of the other compositional analyses from this seep (table 1), and is believed to have been contaminated by air. However, the results for the 2006 analyses did not distinguish between oxygen and argon, making it impossible to calculate the nitrogen:oxygen ratio to establish air contamination.

Isotope analysis of the nearly 87 percent methane fraction in sample 05 PD034 yielded a $\delta 13$ carbon ratio of -39.3 per mil, and $\delta$ deuterium ratio of -195 per mil (table 1). These data are plotted on the natural gas characterization plot (fig. 4; format after Schoell, 1983), and indicate the Aupuk gas seep is clearly thermogenic rather than biogenic in origin, and appears to be a condensate- or oil-associated product generated at oil-window maturity. The 2006 samples were not analyzed for deuterium isotopes, although the two additional carbon isotopic measurements were nearly identical to the 2005 sample (table 1) and appear to be representative of actual current seepage. 


\section{DISCUSSION AND CONCLUSIONS}

The presence of a surface gas seep suggests there is a slowly leaking, thermogenic gas accumulation reservoired in Nanushuk Formation sandstones at depth. The source of this gas is difficult to assess because natural gases do not contain the large, complex biomarker molecules that allow liquid hydrocarbons to be tied back to their specific source rocks. On the basis of its apparent oil-window thermal maturity, it is speculated that the Aupuk seep is probably sourced from gas-prone terrestrial kerogen in the Torok Formation. If migration occurred early in the burial history, then the gas could also be a relict charge from several deeper source rocks that are likely now at much higher maturation levels. These include the Lower Cretaceous gamma ray zone (GRZ, also known as highly radioactive zone, HRZ) and/or pebble shale unit, Jurassic Kingak Formation, and Triassic Shublik Formation, and perhaps other intervals. Finally, given the possibility that polyphase deformation affected this area (O'Sullivan and others, 1997; Finzel and others, 2003), the Aupuk seep could reflect an accumulation of re-migrated hydrocarbons from an earlier episode of trapping.

The trapping mechanism and timing of hydrocarbon migration for the Aupuk gas is unknown, although consideration of local and regional data offers some constraints. Chapman and others (1964) noted that the seep was located near the east end of the Aupuk anticline (fig. 5). The position of the seep near the axis of the structure, as well as evidence for local faulting, support the hypothesis that the gas is leaking from a structurally trapped accumulation. Subsequent mapping in the southern Ikpikpuk Quadrangle by Mull and others (2005) reported additional strike and dip data, further constraining the nature of the Aupuk anticline (fig. 5). Most wells targeting the Nanushuk Formation in the foothills were drilled on structural highs (Mull, 1989) and all the Nanushuk foothills gas discoveries (undeveloped) are reported to be trapped in structural closures (Meade, Square Lake, Wolf Creek, East Umiat, Gubik, and East Kurupa are summarized in Kumar and others [2002]; Oumalik is described in Robinson [1956] and Schindler [1988]).

The timing for the development of this and other folds in the foothills belt could be either mid-Cretaceous (Albian-Cenomanian) or Paleocene. Timing the formation of structural traps in this area is significant because the younger deformation event postdates the principal mid- to Late Cretaceous phase of hydrocarbon generation suggested by burial and thermal history modeling (Burns and others, 2002). In assessing structural plays within NPRA, Potter and Moore (2003) interpreted all of the folding within the Nanushuk belt to reflect deformation at approximately $60 \mathrm{Ma}$, an episode that is widely recorded by apatite fission track data (Moore and others, 2004; O'Sullivan and others, 1997). However, the presence of an earlier phase of mid-Cretaceous folding cannot be ruled out. In fact, there are select fission track data from the central Brooks Range foothills, south of the Nanushuk outcrop belt, that preserve evidence for cooling at 90-110 Ma (Duncan and others, 2006; Cole and others, 1997; O'Sullivan and others, 1997). It is possible that this mid-Cretaceous cooling event affected Nanushuk rocks, but that subsequent burial reset the apatite thermochronometer, potentially erasing any record of pre-60 Ma cooling events (uplift and folding).

The Kurupa anticline (south of the Awuna syncline shown in fig. 5) is approximately $21 \mathrm{~km}$ south of the Aupuk seep and houses the undeveloped East Kurupa gas accumulation within the Torok and/or Fortress Mountain Formations (Kumar and others, 2002). In a study of the thermal maturity of the Torok and Nanushuk Formations involved in this fold, Bird and Pawlewicz (2006) concluded from vitrinite data that folding likely occurred prior to maximum burial, presumably in the mid-Cretaceous. On the basis of seismic and field evidence, other workers have also suggested portions of the Nanushuk Formation were influenced by mid-Cretaceous folding (Wallace, 2003; Finzel and others, 2003; Mull and others, 2000; Cole and others, 1997, Detterman and others, 1963). If additional new data confirm an episode of mid-Cretaceous folding, it would increase the probability of structurally trapped oil and gas accumulations across the Brooks Range Foothills.

\section{ACKNOWLEDGMENTS}

Fieldwork was supported through a combination of State of Alaska budget sources, federal funding distributed through the USGS STATEMAP program, and by substantial contributions from companies and individuals involved in the Alaska oil and gas industry. During 2005, 2006, and 2007, industry sponsors included Anadarko Petroleum Corp., BG Alaska, Chevron, ConocoPhillips Alaska, Inc., Eni Petroleum, Petro-Canada, Pioneer Natural Resources, Repsol YPF Exploration and Production Co., Shell International Exploration and Production Co., and FEX/Talisman Energy, Inc. Petro-Canada graciously paid for and oversaw shipping and analyses for the 2005 Aupuk gas seep sample. This paper benefitted from discussions with D.L. LePain, C.G. Mull, J.G. Clough, and R.F. Swenson as well as a helpful review by G.C. Wilson. 


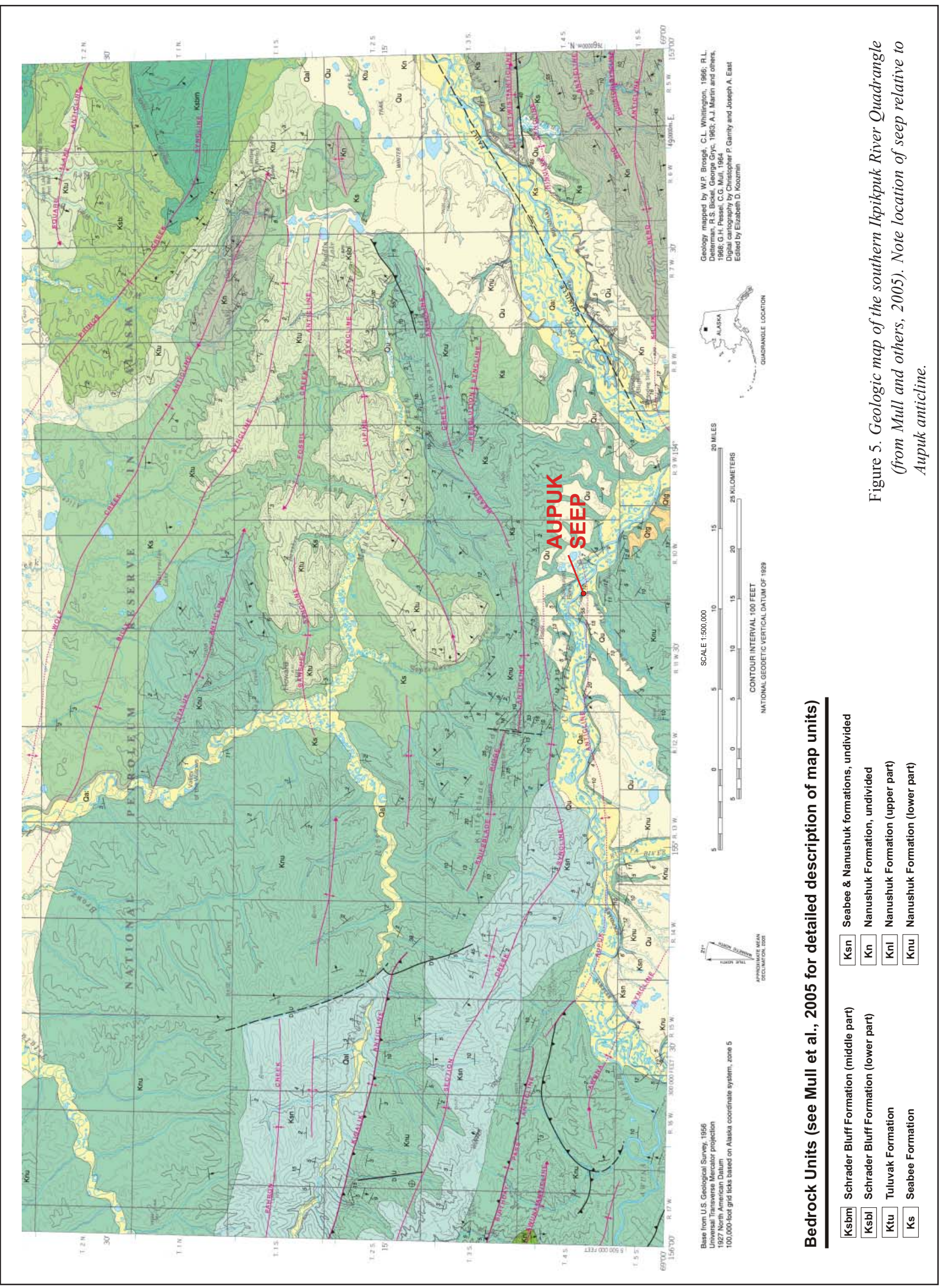




\section{REFERENCES}

Bird, K.J., and Houseknecht, D.W., 2002, U.S. Geological Survey 2002 petroleum resource assessment of the National Petroleum Reserve in Alaska (NPRA): Play maps and technically recoverable resource estimates: U.S. Geological Survey Open-File Report 2002-207, 18 p.

Bird, K.J., and Pawlewicz, M.J., 2006, Thermal maturity and timing of deformation in the foreland basin at Kurupa Anticline, Brooks Range Foothills, Alaska: GSA Cordilleran Section, Abstracts with Programs, v. 38, no. 5, p. 87.

Burruss, R.C., Lillis, P.G., and Collett, T.S., 2003, Geochemistry of natural gas, North Slope, Alaska: Implications for gas resources, NPRA: U.S. Geological Survey Open-File Report 03-341, online publication <http://pubs. usgs.gov/of/2003/of03-041/>.

Burns, W.M., Hayba, D.O., Houseknecht, D.W., and Rowan, E.L., 2002, Timing of hydrocarbon generation in the National Petroleum Reserve-Alaska (NPRA) from burial and thermal history modeling: American Association of Petroleum Geologists Pacific Section and Society of Petroleum Engineers Western Region, Joint Technical Conference Program and Abstracts, p. 66.

Chapman, R.M., Detterman, R.L., and Mangus, M.D., 1964, Geology of the Killik-Etivluk Rivers region, Alaska, U.S. Geological Survey Professional Paper 303-F, p. 325-407, 8 sheets.

Cole, F.E., Bird, K.J., Toro, J., Roure, F., O’Sullivan, P.B., Pawlewicz, M.J., and Howell, D.G., 1997, An integrated model for the frontal Brooks Range and Colville Basin $250 \mathrm{~km}$ west of the Trans-Alaska Crustal Transect: Journal of Geophysical Research, v. 102, p. 20,685-20,708.

Detterman, R.L., Bickel, R.S., and Gryc, George, 1963, Geology of the Chandler River region, Alaska: U.S. Geological Survey Professional Paper 303-E, p. 233-324, 16 sheets, scale 1:125,000.

Duncan, A.S., Hanks, C.L., Wallace, W.K., O’Sullivan, P.B., and Parris, T.M., 2006, Evolution and timing of fractures and related map-scale structures of the central Brooks Range fold-and-thrust belt, northern Alaska: Geological Society of America Abstracts with Programs, v. 38, no. 5, p. 89.

Finzel, E.S., McCarthy, P.J., and Wallace, W.K., 2003, Facies architecture and syntectonic fold geometry of fluvial conglomerate in the Cretaceous Nanushuk Formation, Brooks Range foothills, Alaska: AAPG Pacific Section, Abstracts with Programs, volume and page numbers unavailable.

Garrity, C.P., Houseknecht, D.W., Bird, K.J., Potter, C.J., Moore, T.E., Nelson, P.H., and Schenk, C.J., 2005, U.S. Geological Survey 2005 oil and gas resources assessment of the central North Slope, Alaska: Play maps and results: U.S. Geological Survey Open-File Report 2005-1182, 29 p.

Houseknecht, D.W., and Bird, K.J., 2006, Oil and gas resources of the Arctic Alaska petroleum province: U.S. Geological Survey Professional Paper 1732-A, 11 p.

Kumar, N., Bird, K.J., Nelson, P.H., Grow, J.A., and Evans, K.R., 2002, A digital atlas of hydrocarbon accumulations within and adjacent to the National Petroleum Reserve-Alaska (NPRA): U.S. Geological Survey OpenFile Report 02-71, 80 p.

LePain, D.L., Decker, P.L., and Wartes, M.A., 2008, Measured sections and preliminary interpretations of the Nanushuk Formation exposed along the Colville River near the confluences with the Awuna and Killik rivers, in Wartes, M.A., and Decker, Paul, eds., Preliminary results of recent geologic field investigations in the Brooks Range foothills and North Slope, Alaska: Alaska Division of Geological \& Geophysical Surveys Preliminary Interpretive Report 2008-1, p. 41-45, 4 sheets.

Moore, T.E., Potter, C.J., O’Sullivan, P.B., Shelton, K.L., and Underwood, M.B., 2004, Two stages of deformation and fluid migration in the west-central Brooks Range fold and thrust belt, northern Alaska, in Swennen, R., Roure, F., and Granath, J.W., eds., Deformation, fluid flow, and reservoir appraisal in foreland fold and thrust belts: American Association of Petroleum Geologists Hedberg series, no. 1, p. 157-186.

Mull, C.G., 1989, History of oil exploration on the Arctic Slope, in Mull, C.G., and Adams, K.E., eds., Dalton Highway, Yukon River to Prudhoe Bay, Alaska: Division of Geological \& Geophysical Surveys Guidebook 7, p. 133-140.

Mull, C.G., Harris, E.E., Reifenstuhl, R.R., and Moore, T.E., 2000, Geologic map of the Coke Basin-Kukpowruk River area, DeLong Mountains D-2 and D-3 quadrangles, northwestern Alaska: Alaska Division of Geological \& Geophysical Surveys Report of Investigations 2000-2, 1 sheet, scale 1:63,360.

Mull, C.G., Houseknecht, D.W., Pessel, G.H., and Garrity, C.P., 2005, Geologic map of the Ikpikpuk River Quadrangle, Alaska: U.S. Geological Survey Scientific Investigations Map 2817-B, 1 sheet. 
Nelson, P.H., Bird, K.J., Houseknecht, D.W., Potter, C.J., and Moore, T.E., 2006, Potential tight gas resources in a frontier province-Jurassic through Tertiary strata beneath the Brooks Range foothills, Arctic Alaska: U.S. Geological Survey Open File Report 2006-1172, version 1.0, 2 sheets.

O'Sullivan, P.B., Murphy, J.M., and Blythe, A.E., 1997, Late Mesozoic and Cenozoic thermotectonic evolution of the central Brooks Range and adjacent North Slope foreland basin, Alaska - including fission track results from the Trans-Alaska Crustal Transect (TACT): Journal of Geophysical Research, v. 102, p. 20,821-20,845.

Potter, C.J., and Moore, T.E., 2003, Brookian structural plays in the National Petroleum Reserve, Alaska: U.S. Geological Survey Open-File Report 03-266, 49 p.

Robinson, F.M., 1956, Core tests and test wells, Oumalik area, Alaska: U.S. Geological Survey Professional Paper 305-A, 70 p., 6 sheets.

Schoell, M. 1983, Genetic characterization of natural gases: American Association of Petroleum Geologists Bulletin, v. 67, p. 2225-2238.

Schindler, J.F., 1988, History of exploration in the National Petroleum Reserve in Alaska, with emphasis on the period from 1975 to 1982, in Gryc, George, ed., Geology and exploration of the National Petroleum Reserve in Alaska, 1974-1982: U.S. Geological Survey Professional Paper 1399, 940 p., 58 sheets.

Schuenemeyer, J.H., 1999, Chapter RS, Assessment results, in the oil and gas resource potential of the 1002 Area, Arctic National Wildlife Refuge, Alaska, by ANWR Assessment Team: U.S. Geological Survey Open-File Report 98-34, 2 disks, 12 p., online at $<$ http://energy.cr.usgs.gov/OF98-34/>.

Wallace, W.K., 2003, Geometry and evolution of detachment folds in deformed foreland basin deposits of the Brooks Range Foothills, northern Alaska, abs., in Chidsey, T.C., Jr., ed., 2003 AAPG annual convention with SEPM: Annual Meeting Expanded Abstracts-American Association of Petroleum Geologists, vol.12, p.177. 